\title{
Activating the Zone of Proximal Development of Japanese Language Learners: Language-Exchange Partnerships (LEPs) at an Australian University
}

Hiromi Nishioka

Monash University

\begin{abstract}
This study examines how social interactions in language-exchange partnership sessions can create opportunities for Japanese language learners to use and learn Japanese. The participants in this study were two pairs, consisting of a Japanese native speaker and an Australian studying Japanese at an Australian university. This study, employing Vygotsky's Zone of Proximal Development and assistance to novices by experts, examined what factors enable participants in language-exchange partnerships to provide or receive language assistance within Japanese language learners' zones of proximal development. As a result of the analysis, this study identified two important factors that had this effect: using shared learning experience in language-exchange partnerships, and actively negotiating the level of assistance. Language-exchange partnerships are a new type of learning experience for many participants. It can be anticipated that some participants may struggle to interact and learn from the interaction in the sessions. Therefore, this paper will provide pedagogical suggestions to improve interactions and learning outcomes from language-exchange partnerships. Moreover, suggestions for future research directions are presented in the conclusion of this paper.
\end{abstract}

\section{Keywords}

language assistance; Language Exchange Partnerships (LEPs); out-of-class learning; sociocultural theory; Zone of Proximal Development (ZPD) 


\section{Introduction}

Language Exchange Partnerships (LEPs) are a type of out-of-class learning where language learners meet a native speaker partner of their target language on a regular basis to practice and learn their target language and the culture of their target language. ${ }^{1}$ LEPs are known by a wide range of terms in different institutes of higher education, including 'Language Exchange Program', 'Language Cultural Exchange Program', 'Conversation Partner Programs', 'Conversation Exchange' and 'Tandem Learning.' Growing numbers of Australian universities, including Monash University, the University of Adelaide and the University of New South Wales, have established LEP programs on university campuses to promote interaction between international and Australian students, to allow both groups of students to practice their target language with native speakers, and to help students to learn the culture of their target language. ${ }^{3}$

Language learning in LEPs is based on two basic principles: learner autonomy and reciprocity. ${ }^{4}$ Unlike a classroom learning setting, where teachers plan and control the learning process for learners, LEP participants must take active roles in organising their own learning and deciding their own agenda. ${ }^{5}$ Moreover, drawing on the principle of reciprocity, each participant is expected to contribute equally to the learning of their partner. ${ }^{6}$ LEP participants are usually recruited by distributing advertisements during campus orientation, displaying advertisements on campus bulletin boards or university websites, and by language teachers encouraging their students to participate. ${ }^{7}$ Universities arrange pairs of LEPs based on the participants' target language, their interests and class schedules. ${ }^{8}$ As universities usually expect LEP participants to manage their own learning, the participants discuss with their partners about the frequency and length of sessions, discussion topics and methods for conducting LEP sessions. The participants conduct LEP sessions for 1-2 hours per week on average. ${ }^{9}$

Several studies have pointed out that language learners require a significant amount of exposure to their target language and opportunities to communicate with native speakers for their language development. ${ }^{10}$ In addition, having successful experiences

\footnotetext{
Horiuchi, 'Gakubu ryūgakusei shien jisshi hōkoku'; Nagami, 'Tomodachi to no kaiwa to daini gengo gakushū wa ryōritsu suru ka’; Nishioka, 'Language Assistance in Japanese-English Language Exchange Partnerships (LEPs)'.

Wilson, 'Conversation Partners'; Stoller and Hodges, 'Examining the Values of Conversation Partner Programs'.

Monash University, 'Find Out More about the Language Exchange Program'; The University of Adelaide, 'Language and Cultural Exchange Program'; The University of New South Wales, 'Language and Conversation Skills'.

Little and Brammerts, 'Tandem Language Learning via the Internet and the International E-Mail Tandem Network'.

Woodin, 'Tandem Learning as an Intercultural Activity'.

Little and Brammerts, op. cit.

Masuda, 'Negotiation of Language Selection in Language Exchange Partnerships'.

Matsumoto, 'Kaiwa puroguramu'; Matsumoto, 'Kaiwa pātonā handobukku no sakusei to kaitei'.

Voller and Pickard, 'Conversation Exchange'.

10 Rubin, 'What the "Good Language Learner" Can Teach Us'; Takeuchi, Yori yoi gaikokugo gakushūhō wo motomete.
} 
of interacting with native speakers can further motivate language learners. ${ }^{11}$ In spite of these findings, many students studying Japanese as a foreign language cannot adequately access such learning opportunities because of the small size of the Japanese native speakers' population in their countries. LEPs can increase learning opportunities for Japanese language learners in a foreign-language environment to interact with Japanese native speakers on their campuses. Japanese native speaker students can also benefit from having a more personalised learning environment and establishing social networks with local students.

Although several studies have been conducted in the field of LEPs, these studies are descriptive: they report either the structures of LEP programs, problems that participants encounter, learning outcomes of LEPs, or perceptions of LEP participants and researchers. ${ }^{12}$ These studies have not examined in depth the interactions that occur between Japanese learners and Japanese native speakers in LEPs. However, the learning process and learning outcomes of LEP sessions can be improved by analysing the perceptions of the participants and interactions in LEPs. Therefore, this study will reveal moment-to-moment interactions and language changes of Japanese language learners and Japanese native speakers who are interacting in LEP sessions by employing a microgenetic approach. ${ }^{13} \mathrm{~A}$ microgenetic approach is a mode of qualitative analysis; it allows researchers to reveal the higher mental functions underlying social interactions by analysing moment-to-moment interactions and behaviour changes of the participants. ${ }^{14}$

This study addresses three questions:

1. How do Japanese native speakers anticipate an appropriate level of assistance for their learner interlocutors?

2. How do LEP participants negotiate to receive or provide an appropriate level of language assistance for the Japanese language learner?

3. What types of language assistance do learners of Japanese find difficult to understand?

11 Yorozu, 'Interaction with Native Speakers of Japanese'.

12 Mimaki et al., 'Nihongo gakushūsha to nihongo kyōryokusha ni yoru sōgo katsudō’; Muraoka and Mimaki, 'Ōsaka daigaku toyonaka kyanpasu ni okeru nihongo pātonā no tokusei to katsudō'.

13 de Guerrero and Villamil, 'Activating the ZPD'.

14 Vygotsky, Mind in Society; Wertsch, 'Vygotsky and the Social Formation of Mind'. 


\section{Literature Review}

\section{Language Learning in LEPs}

The purpose of LEP sessions is not only to enjoy chatting with language exchange partners but also to practice and improve target language competency. ${ }^{15}$ In other words, interactions in LEPs have two dimensions: social functions and language learning. Therefore, LEPs serve as a different type of learning opportunity for learners of Japanese compared with daily conversation with Japanese friends or interactions in the classroom. Recent research has revealed how participants' interpretations of LEPs can impact on interactions in LEPs. A study by Nagami confirmed that $30 \%$ of total errors were corrected by Japanese language learners themselves, and that the number of error corrections by Japanese native speakers in LEPs was very limited. ${ }^{16}$ For this reason, Nagami concluded that LEP participants, partly through recognising LEPs as opportunities to have daily conversations with friends, may place more priority on maintaining a smooth flow of conversation than on correcting their interlocutors' errors and thereby disrupting the flow.

Similar to Nagami, a study by Nishioka examines the types of error correction in LEP sessions. ${ }^{17}$ Employing Olsson's classification of error gravity, ${ }^{18}$ Nishioka's study confirmed that lexical errors and the co-occurrence of semantic and syntactic errors are more frequently corrected by Japanese native speakers than one or two syntactic errors, as the former types of errors significantly interfere with the comprehension of interlocutors. The findings of Nagami and Nishioka highlighted the dual dimensions of interactions in LEPs: LEP participants provide language assistance to their partners for their language development, but they also aim to maintain conversation by selectively correcting errors which negatively impact on their comprehension. Consequently, these studies indicated that errors are less likely to be corrected in LEPs, and the participants selectively correct only those errors that interfere with the comprehension of the interlocutors in order to maintain conversation flow.

A study by Masuda ${ }^{19}$ analysing detailed interactions and perceptions of LEP participants examined how they negotiate language use and code-switching in LEP sessions. This study confirmed that LEP participants constantly code-switch languages depending on the immediate communication context or their communication purposes. Listing other

\footnotetext{
15 Masuda, op. cit.

6 Nagami, op. cit.

7 Nishioka, op. cit.

18 Olsson, 'Intelligibility'.

19 Masuda, op. cit.
} 
factors for code-switching, Masuda also identified the language fluency level of the speakers or their interlocutors, the language preference of the speakers or their partners, discourse changes and temporary lack of awareness of their partners' competency as language learners.

What emerged from the above three studies is that interactions in LEPs are different from classroom interactions or daily conversations with friends. Similar to classroom interactions, LEPs provide Japanese language learners with opportunities to receive error corrections from their Japanese native speaker interlocutors or correct their own linguistic errors. However, the frequency of error corrections in LEPs is much lower than in the classroom context because participants prioritise the flow of interactions. In spite of the distinctive discourse characteristics and their role in providing out-ofclass learning opportunities, very little research into LEPs has explored how Japanese language learners and Japanese native speakers interact in LEPs to create their own language-learning opportunities. Moreover, second-language researchers have paid little attention to factors such as how Japanese native speakers accurately assess required levels of language assistance for their learner interlocutors, or how LEP participants can negotiate the level of language assistance to provide to learner partners or obtain from Japanese native speakers. To improve the quality of language assistance and learning outcomes in LEPs, more studies should examine these interaction processes.

\section{Language Assistance}

The relationships between language assistance and the impact of language development have been explored in several studies of second-language acquisition. ${ }^{20}$ These studies have been conducted in the context of tutorial sessions in English composition for learners of English as a second language. For example, employing Vygotsky's Zone of Proximal Development (ZPD) and assistance to novices by experts, ${ }^{21}$ Aljaafreh and Lantolf $^{22}$ examined the relationships between different stages of language development and the impact on the effectiveness of language assistance to them. Vygotsky ${ }^{23}$ defined the ZPD as the difference between the 'actual developmental level' at which a child or a novice can solve a problem individually, and his/her 'level of potential development' that he/she can accomplish through collaboration with an adult or a more capable person. $\mathrm{He}$ asserts that collaborative assistance from an expert allows the novice to achieve what he or she cannot accomplish alone. Gradually, a novice becomes able to achieve the

\footnotetext{
20 Aljaafreh and Lantolf, 'Negative Feedback as Regulation and Second Language Learning in the Zone of Proximal Development'; Nassaji and Swain, 'A Vygotskian Perspective on Corrective Feedback in L2'.

Vygotsky, op. cit.

Aljaafreh and Lantolf, op. cit.

23 Vygotsky, op. cit., p. 85.
} 
task with little assistance from an expert as their higher mental functions develop, and finally the novice becomes able to achieve the task by him or herself. ${ }^{24}$ Wertsch defined such a transition from interpsychological to intrapsychological functions as transition from 'other-regulation' to 'self-regulation'. ${ }^{25}$

To operationalise the concept of the ZPD and level of required language assistance, Aljaafreh and Lantolf ${ }^{26}$ assessed each participant's ZPD by applying scales for different developmental stages proposed by Wertsch ${ }^{27}$ and Wertsch and Hickmann. ${ }^{28}$ Moreover, to distinguish the explicitness of language assistance from the tutor, Aljaafreh and Lantolf developed regulatory scales from other-regulation to self-regulation based on twelve levels. By employing both scales, Aljaafreh and Lantolf demonstrated that learners in different developmental stages require different levels and amounts of language assistance from an expert; learners in higher developmental stages can easily identify their language errors with less explicit assistance from a tutor and solve problems within shorter interactions, whereas learners at a lower developmental stage require more explicit assistance from the tutor and longer interactions to solve their language problems.

In addition, Aljaafreh and Lantolf confirmed that English language learners begin to easily solve their language problems with less explicit assistance within shorter interactions when they encounter similar language problems, both inter-session and intra-session. Another important contribution of Aljaafreh and Lantolf to second-language research is the identification of three essential conditions for successful assistance: graduated, contingent and dialogic. The authors defined graduated assistance as 'the appropriate level of assistance to encourage the learner to function at his or her potential level of assistance. ${ }^{29}$ The expert is expected to accurately assess the minimum level of assistance required for the novice, and strategically move the assistance from implicit to more explicit in response to the novice's reactions. As the second condition, Aljaafreh and Lantolf ${ }^{30}$ assert that language assistance should be contingent: offer it only when the novice needs it, and withdraw it as soon as the novice starts to function independently. As the third condition, Aljaafreh and Lantolf argue that successful assistance is provided in the dialogic activity that unfolds between the expert and novice. The authors stress the important roles of dialogue for successful assistance by saying that dialogic negotiation between expert and novice allows the expert to discover the novice's ZPD. Thus, their study sheds light on the conditions required to provide effective language assistance to language learners.

24 Vygotsky, op. cit., pp. 84-91.

Wertsch, 'From Social Interaction to Higher Psychological Processes', op. cit., p. 17.

Aljaafreh and Lantolf, op. cit.

Wertsch, 'The Zone of Proximal Development'.

Wertsch \& Hickmann, 'Problem Solving in Social Interaction'

Aljaafreh and Lantolf, op. cit., p. 468.

30 ibid. 
Drawing upon Aljaafreh and Lantolf, ${ }^{31}$ a case study by Nassaji and Swain ${ }^{32}$ compared the effectiveness of language assistance within the learner's ZPD and random levels of assistance for article usage in composition conference between two English language learners and a tutor. To operationalise differences of assistance, a tutor gradually increased the explicitness of language assistance to a learner with his or her ZPD treatment based on the regulatory scale by Aljaafreh and Lantolf. Random levels of language assistance were provided to the learner with non-ZPD treatment. Both learners received the treatment for 40 minutes for five weeks in tutorials. Their study confirmed that language assistance within the learner's ZPD is more effective in eliciting appropriate responses from the learner within shorter interactions than randomly providing language assistance. Moreover, their study demonstrated that the learner with his or her ZPD treatment significantly outperformed the learner with non-ZPD treatment in the posttest stage, although the learner with non-ZPD treatment demonstrated a higher score than the learner with their ZPD treatment at the pre-test stage.

Studies by Aljaafreh and Lantolf and Nassaji and Swain have confirmed that language assistance from experts to novices can facilitate language development of Englishlanguage learners, both inter-session and intra-session. These studies have also contributed towards demonstrating that learners in different stages of development require different levels of assistance from experts. Moreover, Nassaji and Swain's study revealed that language assistance within the learner's ZPD more significantly impacted on his or her learning outcomes in the long term, compared with assistance that is out of the learner's ZPD. However, these studies were conducted in the context of a writing conference between English language learners and tutors, and very little research has examined how Japanese native speakers and Japanese language learners interact and create learning opportunities for learners of Japanese in LEPs. To improve the quality of interactions and learning outcomes in LEP sessions, it is important to examine how both Japanese-language learners and Japanese native speakers interact in LEP sessions, what factors enable them to provide or receive language assistance within the ZPD of Japanese learners, and what types of communication problems LEP participants encounter during LEP sessions. 


\section{Methodology}

\section{Participants}

This study involved two pairs of participants, each consisting of a Japanese native speaker and an Australian learner of Japanese who both study at an Australian university. The details of the participants' demographic data are presented in Table 1. All participants were volunteers recruited through posters displayed on campus for several weeks, or by invitation from the researcher or the researcher's colleagues. The researcher matched the two pairs based on their class schedules. Both pairs consisted of an Australian male undergraduate student enrolled in high intermediate Japanese, which targets students with equivalent to Level 2 (high intermediate) in the pre-2010 version of Japanese Language Proficiency Test ${ }^{33}$ and a Japanese female graduate student who studied at the same Australian university with the Australian participants. Prior to their first LEP session, the participants were informed by the researcher that they could decide how they would conduct their own LEP sessions by selecting the teaching methods, topics and time allocation for each language. However, this study did not provide prior pedagogical training to the participants. Universities only advertise the programmes and help to match pairs. The participants were expected to explore and negotiate how they interact in LEP sessions through trial and error, as seen in Nagami ${ }^{34}$ and Masuda. ${ }^{35}$

LEPs are based on the reciprocal principle: participants are expected to devote the same amount of time and energy to each participant's target language ${ }^{36}$ However, there is some group variation in how the participants allocate their language uses in LEP sessions, depending on their language preferences and their perceived reasons for participation in LEP sessions. One pair of participants, Sutono and Eri, chose to distribute one language to one half of the session, and automatically code-switched whenever their communication broke down ${ }^{37}$ On the other hand, the other pair, Paul and Hiroko, chose to use Japanese as their dominant language during LEP sessions. As to the reasons, Hiroko explained in a semi-structured interview that she gave away her opportunities to practice her target language because she has plenty of opportunities to speak in English outside LEP sessions since she lives in Australia. She also added that she thus recognises LEPs as opportunities to learn about Australian culture rather than

33 The Japanese Language Proficiency Test (JLPT) is sponsored by The Japan Foundation and the Japan Educational Exchanges and Service. The format of the JLPT was modified to assess communicative skills in 2010. In addition, to assess fluency levels more precisely, the level divisions were also modified from 4 levels (from Level 1 to Level 4, where Level 1 is the highest level) to 5 levels (from N1 to N5, where N1 is the highest level). The details of format changes and the current test format can be seen on the Japan Foundation website (http://www.jpf.go.jp/j/japanese/new/1010/10-02.html) and the Japan Educational Exchanges Service website (http://info.jees-jlpt.jp/?lang=english).

34 Nagami, op. cit.

35 Masuda, op. cit.

36 Little and Brammerts, op. cit.

37 Pseudonyms are used to protect participants' privacy. 
to practice her English. In the LEP sessions, each pair interacted for approximately one hour, either in a chatting space in a university library or a coffee shop on campus. LEP sessions were conducted approximately seven to eight times over two months so that participants could familiarise themselves with their partners and LEP sessions.

Table 1. Demographic Data of the LEP Participants

\begin{tabular}{|c|c|c|c|c|}
\hline & \multicolumn{2}{|l|}{ Pair 1} & \multicolumn{2}{|l|}{ Pair 2} \\
\hline & Paul & Hiroko & Sutono & Eri \\
\hline First language & English & Japanese & English & Japanese \\
\hline Gender & Male & Female & Male & Female \\
\hline Age & 19 years old & 25 years old & 20 years old & 27 years old \\
\hline Education & Undergraduate & Postgraduate & Undergraduate & Postgraduate \\
\hline Fluency level & $\begin{array}{l}\text { Enrolled in high- } \\
\text { intermediate } \\
\text { Japanese }\end{array}$ & IELTS 7.5 & $\begin{array}{l}\text { Enrolled in high- } \\
\text { intermediate } \\
\text { Japanese and } \\
\text { Chinese } \\
\end{array}$ & IELTS 6.5 \\
\hline $\begin{array}{l}\text { Length of } \\
\text { English/ } \\
\text { Japanese } \\
\text { learning }\end{array}$ & $\begin{array}{l}\text { Studied Japanese } \\
\text { for eight years. }\end{array}$ & $\begin{array}{l}\text { Studied English } \\
\text { for thirteen years. } \\
\text { Graduated from } \\
\text { an Australian } \\
\text { university. }\end{array}$ & $\begin{array}{l}\text { Studied Japanese } \\
\text { for fourteen } \\
\text { years, since third } \\
\text { year at primary } \\
\text { school. }\end{array}$ & $\begin{array}{l}\text { Studied English } \\
\text { for fourteen } \\
\text { years. }\end{array}$ \\
\hline $\begin{array}{l}\text { Length of } \\
\text { staying in } \\
\text { Japan/Australia }\end{array}$ & $\begin{array}{l}\text { Stayed for four } \\
\text { weeks in Japan on } \\
\text { a school trip. }\end{array}$ & $\begin{array}{l}\text { Lived in Australia } \\
\text { for six years. }\end{array}$ & $\begin{array}{l}\text { Stayed in Japan } \\
\text { for one year as an } \\
\text { exchange student } \\
\text { during high } \\
\text { school. }\end{array}$ & $\begin{array}{l}\text { Stayed for ten } \\
\text { months in } 2004 . \\
\text { Stayed for one } \\
\text { and a half years } \\
\text { from } 2007 \text { to } \\
2008 .\end{array}$ \\
\hline $\begin{array}{l}\text { Opportunities } \\
\text { to speak } \\
\text { outside the } \\
\text { classroom }\end{array}$ & $\begin{array}{l}\text { Spoke Japanese } \\
\text { for one hour per } \\
\text { week in LEPs. }\end{array}$ & $\begin{array}{l}\text { Spoke English } \\
\text { with flatmates } \\
\text { and friends } \\
\text { almost every day. }\end{array}$ & $\begin{array}{l}\text { Spoke Japanese } \\
\text { four hours } \\
\text { per week with } \\
\text { four exchange } \\
\text { partners in LEPs. }\end{array}$ & $\begin{array}{l}\text { Spoke English } \\
\text { with friends every } \\
\text { day. }\end{array}$ \\
\hline $\begin{array}{l}\text { Reason to } \\
\text { participate in } \\
\text { LEP }\end{array}$ & $\begin{array}{l}\text { To know about } \\
\text { Japanese culture. } \\
\text { To practice } \\
\text { listening and } \\
\text { speaking outside } \\
\text { the classroom. }\end{array}$ & $\begin{array}{l}\text { To get to know } \\
\text { more about } \\
\text { Australian } \\
\text { culture. }\end{array}$ & $\begin{array}{l}\text { To speak more } \\
\text { Japanese. }\end{array}$ & $\begin{array}{l}\text { To have more } \\
\text { chance to talk to } \\
\text { native speakers } \\
\text { and brush up her } \\
\text { speaking ability. }\end{array}$ \\
\hline
\end{tabular}




\section{Data Collection}

Three types of data collection methodology were employed in this study: a semistructured interview, audio-recordings of naturally occurring interactions during LEP sessions, and stimulated recall. Prior to commencement of the study, semi-structured interviews were conducted to collect the participants' background information and their motives for participating in LEPs. Semi-structured interviews were also employed to obtain further perceptions from the participants. Audio-recordings were taken to gather data of naturally occurring interactions in LEP sessions. To analyse LEP interactions in detail, all recorded data were transcribed by the researcher adhering to transcription conventions outlined by Markee. ${ }^{38}$ The focus of this study was to examine the process of negotiating language assistance for Australian learners of Japanese with Japanese native speakers in LEP sessions; therefore, only interactions conducted primarily in Japanese were extracted for analysis. This study collected recording data of the last three sessions out of a total of seven to eight sessions from each pair. As Eri and Sutono equally allocated their time for each target language, approximately 90 minutes in total of recorded data from their last three sessions were extracted for data analysis. As Hiroko and Paul conducted their LEP sessions primarily in Japanese in all of their sessions, all recorded data from their last three sessions - lasting approximately 3 hours in total - were included for analysis.

Shortly after each LEP session, stimulated recall sessions were conducted with both the Japanese language learner and Japanese native-speaker participants. Stimulated recall is a methodology which encourages participants to recall their thoughts at the moment of a specific event through stimulus such as video or audio recordings of the interaction or their own written work. ${ }^{39}$ During data collection by stimulated recall, the participants were encouraged to pause the tape at any moment they wished to articulate their thoughts about a specific point. The researcher could also pause the tape whenever they wished to elicit a participant's perceptions of a specific learning event. ${ }^{40}$ Mackey et al., ${ }^{41}$ for example, employed stimulated recall to confirm to what extent Englishlanguage learners accurately recognised the nature of given corrective feedback while they were engaged in a task. Morris and Tarone ${ }^{42}$ demonstrated by using stimulated recall how learners' perception of their classmates can impact on their interpretation of the corrective feedback given by their peers. Thus, these studies demonstrate that stimulated recall can serve as a valuable data collection tool in second-language acquisition research. Stimulated recall allows researchers to access the perceptions of

\footnotetext{
38 Markee, Conversation Analysis, pp. 167-168.

39 Mackey et al., 'How Do Learners Perceive Interactional Feedback?'

40 Gass and Mackey, Stimulated Recall Methodology in Second Language Research, p. 28.

1 Mackey et al., op. cit.

42 Morris and Tarone, 'Impact of Classroom Dynamics on the Effectiveness of Recasts in Second Language Acquisition'.
} 
the participants, which are difficult to obtain otherwise. ${ }^{43}$ This study employed stimulated recall sessions to elicit the participants' perceptions of interactions during LEP sessions, as well as other underlying factors impacting on interactions in LEP sessions.

\section{Data Analysis}

To analyse interactions during LEP sessions, this study employed microgenetic analysis, which was proposed by Vygotsky. ${ }^{44}$ Microgenetic analysis is a qualitative, interpretive, casestudy perspective on L2 instruction that allows the observation of language development at the very moment it is thought to occur ${ }^{25}$ As to relationships between psychological development and microgenetic analysis, Vygotsky states that any psychological development is 'a process undergoing changes right before one's eye' ${ }^{46} \mathrm{He}$ also asserts that psychological development can be traceable under certain conditions. By qualitatively analysing moment-to-moment interactions and the changes to the participants' behaviour during a learning event, researchers can reveal how higher mental functions develop in social interactions. ${ }^{47}$ This study, by employing microgenetic analysis, examines language developments of Japanese language learners in LEPs, how Japanese native speakers and Japanese learners interact in LEP sessions, and how their Japanese language changes and develops in moment-to-moment interactions in LEP sessions.

\section{Findings}

The analysis indicated that the Japanese native speaker participants in this study can provide language assistance within the ZPD of their Japanese learner interlocutors in LEP sessions, and also confirmed that several factors allowed these native speakers to identify and provide the required level of language assistance to their learner interlocutors.

\section{Shared Learning Experiences}

The first extract was recorded while Hiroko was explaining the matriculation examination system in Japan to Paul. This extract demonstrates how a Japanese native speaker uses shared learning experiences with her partner in LEPs to assess the needs for assistance of her Japanese learner partner.

\footnotetext{
3 Nunan, Research Methods in Language Learning, pp. 94-96.

44 Vygotsky, op. cit., p. 61.

45 de Guerrero and Villamil, op. cit., p. 54.

46 Vygotsky, op. cit., p. 61

47 ibid., p. 61; Wertsch, 'Vygotsky and the Social Formation of Mind', pp. 54-57; de Guerrero and Villamil, op. cit.
} 


\section{Extract 1.}

1 Paul: みんなの高校三年生は(+)英語を-やら-やらなければなりません.

Every third-year high school student has to study English

2 Hiroko: うん(+)ですね:::

Yes, that's right

日本(の高校のカリキュラム)は::: そ:::んなにflexibleじゃない-かな？

The Japanese (high school curriculum) is not so flexible, I think ビジネスはまずありません $(+++)$

Needless to say, we do not have subjects about business

うん-でえつと::: (+) 私が高校三年生のとき-は

Yes, and, well, when I was a third year student

えつと::: 英語? 日本語？あとはえつと::: 日本の歴史-か世界の歴 史一竟巽べます $(++)$

Well, we could choose from English, Japanese subjects (for Japanese high school students) and well, Japanese history or world history で-日本語もたくさんありますね:::

And, we had different types of Japanese subjects (for Japanese high school students) えつと::: (+) 古典 $(+)$ 分かりますか? $(++)$

Well, do you know classical Japanese?

クラッシックなジャパニーズ(hhh)

Classical Japanese ((laughter))

3 P: 古典 //難しい//

Classical Japanese, difficult

$4 \mathrm{H}: \quad / /$ 難しいですね//

Difficult

古典があって-あと漢文 $(+)$ Chineseですね $(+)$ 漢文があって漢字 オンリー(hhh)

We have classical Japanese, and classical Chinese poems which are written only in Chinese characters ((laughter))

全部漢字です

Everything is written using only Chinese characters 
What is important to notice in Extract 1 is Hiroko's strategic code-switching and paraphrasing into high frequency words. Academic subject names, which are frequently used in a wide range of contexts, such as ‘英語 (eigo; English)' and '歴史 (rekishi; history)', are introduced in Japanese, whereas low-frequency words such as '古典 (koten; classical Japanese)' and '漢文 (kanbun; classical Chinese poem)' are introduced in English. In addition, another low-frequency word, '国語 (kokugo; a Japanese language subject for Japanese native speakers)' is paraphrased as a high-frequency word, '日本語 (nihongo; Japanese language)'. Interestingly, Hiroko switches back to Japanese immediately after these code-switches and paraphrases. To examine correlations between Hiroko's vocabulary assistance and the vocabulary level, this study used the text, Reading Chüta, to ascertain the vocabulary level according to the pre-2010 version of the Japanese Language Proficiency Test. ${ }^{48}$ According to Reading Chüta, '英語 (English)' and '歴 史 (history)', which Hiroko introduced in Japanese, are identified as Levels 4 and 3 respectively. On the other hand, '古典 (classical Japanese)' and '漢文 (classical Chinese poem)', which Hiroko code-switched into English, were indicated to be Level 2. '国語 (a Japanese-language subject for Japanese native speakers)', which Hiroko paraphrased with a high-frequency word, was indicated as being beyond Level 1.

Regarding her selective code-switching, Hiroko explains in a stimulated recall session that she had anticipated that Paul might not know the meanings of '古典 (classical Japanese)' and '漢文 (classical Chinese poem)' and therefore translated them into English. Paul admits in stimulated recall that he could not spontaneously recall both words for the academic subjects in Japanese. What these examples indicate is that Hiroko accurately anticipates the words Paul has yet to learn, and provides minimum translation for challenging lexical items. In other words, Hiroko's assistance is graduated because she accurately assesses the minimum level of assistance Paul needs. In addition to being graduated, her assistance is contingent because she withdraws her assistance and switches back to Japanese from English immediately after translating low-frequency lexical items such as '古典 (classical Japanese)' and '漢文 (classical Chinese poem)'. In a stimulated recall session, Paul expresses appreciation for her English translations of challenging vocabulary and paraphrasing into high-frequency words. Hiroko also asserts in stimulated recall that she thought Paul would have been overwhelmed by unfamiliar words and fallen into a panic if she did not code-switch, and as a result, would not have been able to understand the general meaning of their dialogue.

48 Kawamura, 'Goi chekkā wo mochiita dokkai tekisuto no bunseki'; Kawamura, 'Intānetto jō de riyō kanōna bunshō no nan'ido sokutei shisutemu no kaihatsu'. 
Given that Hiroko accurately anticipates the words Paul has yet to learn, code-switches or paraphrases only these words, and immediately switches back to his target language afterwards, it can be said that her language assistance to Paul is within his ZPD. As to the reasons for her accurate sense of Paul's ZPD, Hiroko explains in stimulated recall that she has recognised his competency level and vocabulary size through dialogue with him over several LEP sessions. Besides opportunities to converse with him, she adds that looking at his course assignments and textbook also help her to assess his current language level. In other words, opportunities to have conversation with Japanese language learner partners and use their shared learning experiences in LEPs allowed Hiroko to assess Paul's vocabulary size accurately. Consequently, Japanese native speakers can provide Japanese-language learners with a minimum level of assistance to maintain ongoing interactions, and then withdraw assistance when Japanese language learners show 'signs of self-control and ability to function independently' ${ }^{9}$

\section{Negotiating the Level of Assistance}

Negotiating the level of assistance with interlocutors is another essential condition of providing or obtaining language assistance within the ZPD of Japanese language learners in LEPs. The following conversation was recorded when Eri was asking Sutono if he felt he had reached his limit while he was studying Japanese.

\section{Extract 2.}

1 Eri: でもな $(+)$ あの:: え-日本語でな::: 何か限界感じた (genkai kanjita)こと がある?何か

But well, have you ever felt you have reached your limit while you were studying Japanese?

2 Sutono: 限界感?(genkaikan)

Feel (that I have reached my) limit?

3 E: うんまだないか

Yes, you haven't felt that yet, have you?

4 S: $\quad$ かんは $(+)$ あの:::ビルでしょ?

(The last Chinese character of '限界感 (genkaikan)'), '感 (kan)', represents a building, doesn't it?

49 Aljaafreh and Lantolf, op. cit., p. 468. 
5 E: $\quad$ ビル?

Building?

6 S: 限界感 (genkaikan) //あの::://

Feel (that I have reached my) limit?, well

$7 \mathrm{E}: \quad / /$ 違う違う// (hhh)

No, no ((laughter))

$8 \mathrm{~S}: \quad$ 水族館 (suizokkan)

Aquarium?

$9 \mathrm{E}: \quad$ 違う違う (hhhh)

No, no ((laughter))

10 S: あそう?

Oh, really?

$11 \mathrm{E}:$ そうそうとか (hhh)

Yeah, yeah ((laughter))

$12 \mathrm{~S}: \quad$ (hhh) そうそうビルですよ,ビルじゃない？

((Laughter)) Yeah, yeah, (The last Chinese character of “限界感

(genkaikan)' (limit) represents a building, doesn't it ?

$13 \mathrm{E}: \quad$ (hhh) 限界 (+) 限界わかる?

((Laughter)) Limit, do you understand limit?

$14 \mathrm{~S}: \quad$ 階段の階?

(Is '界 (kai)' in '限界 (genkai; limit)' the same Chinese character as) '階 (kai)' in '階段 (kaidan; steps)'?

$15 \mathrm{E}: \quad$ No

No

16 S: No? 調べとこうか

No? Shall I consult a dictionary?

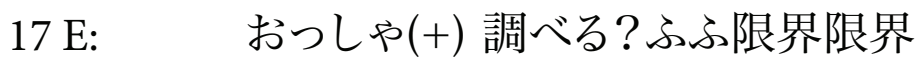

Yes, do you want to consult a dictionary? Haha limit, limit

$18 \mathrm{~S}: \quad$ 限界感 $(++)$ たぶん見て::: なんとなく見たこと

//あるかな:://

Feel (that I have reached my) limit, Maybe I have seen (the word before) ((The expression is grammatically inaccurate, so Sutono stopped in the middle of his utterance to reorganise the sentence), I think that I have seen it somewhere. 
$19 \mathrm{E}:$

$$
\text { //うんうん// あるたぶんある }
$$

Yes, yes, you have probably seen it before

((辞書で調べているストノを見ながら)) 限界 (+) 限界

((While looking at Sutono consulting a dictionary)) Limit, limit

20 S: 限界

Limit

((辞書にある「限界」を意味する漢字を指しながら))

((by pointing out the correct Chinese character for ‘限界 (genkai; limit)'))

あの::: (++) この限界?

Well, is this Chinese character '限界 (genkai; limit)'?

$21 \mathrm{E}: \quad$ ピンポーン

That's correct

Eri's question in Turn 1 of Extract 2 can be translated literally into English as 'In Japanese, have you ever felt your limit?'. An equivalent English expression would be 'Have you ever felt you have reached your limit, or have you ever felt you have reached your personal best while you were studying Japanese?'. Sutono's unfamiliarity with the lexicon is made obvious by his misunderstanding ‘限界を感じる (genkai wo kanjiru; feel oneself have reached one's limit)' in Turn 1 as ‘限界感 (genkaikan; feeling that one had reached one's limit)', and by repeating the wrong word in Turn 2. However, Eri wrongly interprets Sutono's repetition in Turn 2 as a sign that he is trying to express that he has never felt he has reached his limit while studying Japanese, and continues to say ‘うんま だないか (Yes, you haven't felt that yet, have you?)’. Eri admits in stimulated recall that she finally realised Sutono had not understood the meaning of '限界 (genkai; limit)' when Sutono asked her, 'かんは (+) あの:::ビルでしょ?’ ((The last Chinese character of ‘限界感 (genkaikan)’), '感 (kan)', represents a building, doesn’t it?) in Turn 4.

Having advance knowledge of Chinese characters as a learner of Japanese and Chinese, Sutono employs several communication or learning strategies to retrieve vocabulary or understand vocabulary in ongoing interactions. His strategy repertoires which he listed in a stimulated recall interview were: ask a native speaker how to write the word in Chinese characters; brainstorm words which have the same or similar sounds; and look at Chinese characters and guess the meaning from them. Taking interactions from Turns 8 to 14 as an example, Sutono brainstorms words that he has learned already and attempts to use the sound of kan to understand the meaning of '限界感 (genkaikan). Sutono recalls that '水族館 (suizokkan; aquarium)' also shares the same sound of kan with 限界感 (genkaikan). He is hypothesising that the last Chinese character of '限界感 
(genkaikan)' is the same as the last Chinese character in '水族館 (suizokkan)'. To confirm his hypothesis, Sutono poses the question to Eri by saying, '水族館 (suizokkan)?' in Turn 8. To Sutono's question, Eri replies by saying, '違う違う(No, no)', and maintains her assistance to Sutono at a minimum level. Her minimum assistance encourages him to keep generating hypotheses for the meaning of '限界 (genkai; limit)', and testing the hypotheses. Finally, Sutono, who cannot hypothesise anymore, asks Eri if he can consult a dictionary in Turn 16, saying, '調べとこうか (Shall I consult a dictionary?)'. If she provides the English translation, it would be much quicker for Sutono to know the meaning. However, Eri surmises that Sutono can learn more by thinking by himself or consulting a dictionary by himself. It can be said that her intentional minimum intervention reflects her determined belief that language assistance should be graduated and contingent. ${ }^{50}$

Inexplicit language assistance may move towards being more explicit when Japaneselanguage learners seek a more explicit form of language assistance from Japanese native speakers. The extract below was taken when Eri was asking Sutono to make a model sentence using ‘限界を感じる (genkai wo kanjiru)’ in English.

\section{Extract 3.}

1 Eri:そそれentenceにして私が限界を感じる

Can you make it into a sentence? I feel I have reached my limit

2 Sutono: ああ:: たぶん ((考える))

Oh, probably ((thinks))

3 E: ガんばれがんばれがんばれ (hhh)

You can do it, you can do it, you can do it ((laughter))

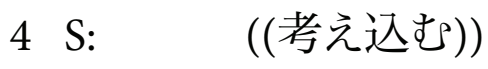

((Thinks for a while))

我慢の限界だったみたいな

(Do you mean) the end of my patience?

5 E: (+) 我慢の限界だった? 我慢の限界だったちょつと違うな::: (hhh)

End of my patience? end of my patience, it sounds different ((laughter))

I could not endure anymore みたいな:::

(Could you make a sentence) such as I could not endure anymore 
6 S: 限界効用?

Effect of limit

7 E：限界効用? 何じゃそら?聞いたことない:::

Effect of limit, what is it? I have never heard of it

8 S: あ-そう？

Oh, really?

9 E: 効用?

\section{Effect?}

10 S: ～たぶん $(+) / /$ 限界感つて::://

Probably, limit is

$11 \mathrm{E}:$

//限界感 // (+) 限界を感じた

Feel (that I have reached my) limit, I felt I had reached my limit

12 S: 何かもう:::何か意味はあまりよく分からない(+)//あの::://

Well, I cannot understand the meaning clearly, well

$13 \mathrm{E}:$

$$
\text { //あ:::// }
$$

$\mathrm{Oh}$

14 S: 分かるけどどう言うあの日本語でどういう例文？

I understand, but how (do you) say? Well, how (can you make) the model sentences in Japanese?

$15 \mathrm{E}:$ 例文? 例えば $(++)$ えつと::: $(+++)$ 例えば $(++)$ 例えば $(+)$ 一生懸命 テスト//勉強しました//

Model sentences? For example, well, for example, for example, I studied really hard

$16 \mathrm{~S}:$

$$
\text { //あ:::// }
$$

$\mathrm{Oh}$

17 E: $\quad$ でも::: テストがあまりにも難しかつたので-限界を感じました But, the test was so difficult, I felt I had reached my limit

18 S: あ:::

$\mathrm{Oh}$

$19 \mathrm{E}:$ もう難しすぎたから $(+)$ 自分の限界は(+)もう//超えていた $/ /$

(The test was) so difficult, I felt I had already surpassed my limit 20 S:

//あ::://

Oh 
Although Sutono has already consulted a dictionary, it is obvious that his understanding of the phrase remains at the surface level because of his struggle to make model sentences with the expression. Finally, Sutono reveals his difficulties in making the model sentence by saying, 何かもう::: 何か意味はあまりよく分からない (Well, I cannot understand the meaning clearly)' in Turn 12, and explicitly seeks Eri’s help by saying, “分かるけどど う言うあの日本語でどういう例文? (I understand, but how do you say? Well, how can you make the model sentence in Japanese?)' in Turn 14. With Sutono's request for more explicit assistance, Eri, who has maintained minimal assistance so far, contextualises the expression in Turns 15 and 17, and demonstrates how to use the phrase in a reallife context in Japanese. Moreover, she adds a similar expression to ‘限界を感じる (feel one has reached one’s limit), “自分の限界は (+) もう//超えていた// (I felt I had already surpassed my limit)', in Turn 19. The interactions in Extract 3 revealed the processes by which a Japanese native speaker and a Japanese language learner negotiate what degree of language assistance to seek or provide through their dialogue in LEPs. As Aljaafreh and Lantolf ${ }^{51}$ claim, such dialogic negotiation between Japanese native speakers and Japanese language learners forces the Japanese native speaker to discover their learner partner's ZPD, and provide language assistance to activate the ZPD of their learner interlocutors in LEPs.

\section{Scaffolding, which Cannot Activate the Japanese Language Learner's ZPD}

The above three extracts demonstrate how the Japanese native-speaker participants in this study are capable of assessing the required level of assistance for their learner interlocutors and providing language assistance which activates their ZPD in LEP sessions. On the contrary, careful investigation of the interactions in LEPs also revealed that some given language assistance was much beyond the learner's ZPD level and was not understood by Japanese language learners. The following example was collected when Hiroko and Paul were talking about the entrance examination system in Japan.

\section{Extract 4.}

1 Paul: (推薦入学の人は) 試験-しなくてもいい?

(Students entering university with a school recommendation) do not have to take entrance examinations?

2 Hiroko: 試験はときどきあります-が試験はありますが大体全員パス $(++)$

Sometimes they have to take examinations, but usually everyone passes 


\section{うん高校の成績がいいので大体パス}

Well, their grades in high school are good, most applicants pass the examination

面接-があります-が形だけ? (++ ) just only do that for whatever (hhh)

There is an interview, but it is only pro forma ((laughter))

形だけ-で意味はありません

(The interview) is only pro forma, it does not have any evaluation function

3 P: (推薦入学で $) \mathrm{T}$ 大学((有名国立大学)) もW大学((有名私立大学))も $(++)$ 入れますか

Can (students) enter $\mathrm{T}$ university ((a prestigious national university in Japan)) and W university ((a prestigious private university in Japan)) only with a school recommendation?

$4 \mathrm{H}$ : 入れません

(They) cannot enter (these universities only with a school recommendation)

5 P: 入れません

(They) cannot enter (these universities only with a school recommendation)

$6 \mathrm{H}: \quad$ えつと:::私立-の学校 only

Well, (they can) only (enter) private schools (with a school recommendation) 国立はだめですね::: (++)

(There is) no national university (which accepts students only with a school recommendation)

でもえつと T大学はだめです-が $(+)$

But, well, although (they) cannot (enter) T university W大学-はあります

(they can enter) $\mathrm{W}$ university (only with a school recommendation) 私の友達はえつと::: 先生の- recommendation $(+)$ 推薦で-

My friend, well, with a teacher's recommendation letter $\mathrm{W}$ 大学一に入りました $(++)$

Entered W university で-高校の成績がよかつたすごくよかつたです $(++)$

And her grade in high school was good, so great で-先生が- W大学-にこの子はどうですか-と言つて

And her teacher asked W university to allow her (to enter W university) 
W大学- がじゃ::: 簡単なテストをして $(+)$ 面接をして

And $\mathrm{W}$ university had conducted a very simple test and an interview (with my friend)

(+)で入りました

And (she) entered (W university)

In Turn 2 in Extract 4, Hiroko is explaining that Japanese students who aim to enter a university with a school recommendation sometimes have to take an examination. Hiroko, by saying “面接-があります-が形だけ?’ in Turn 2, is attempting to explain that the entrance examination for the recommended students is only a matter of form and it does not have an evaluative function. Hiroko anticipated that Paul may not understand the expression, and she provides a Japanese translation by saying 'just only do that for whatever'. However, Paul admits in the stimulated recall session that her English translation in Turn 2 did not help him to understand the meaning of the phrase. To understand “面接-があります-が形だけ?’, Japanese learners would need to be familiar with low-frequency words and to understand that '形だけ' means 'pro forma'. In addition, learners are expected to be familiar with the Japanese entrance examination system. Given the complexity of the expression, Hiroko should have more explicitly defined the meaning and have provided concrete examples in the subsequent turn. The assistance Hiroko provided in Turn 2 could be contingent, because she immediately switched back to English, but it is not graduated because her explanation is not explicit enough for Paul's fluency level.

At the end of Turn 6, Hiroko indeed briefly paraphrases the phrase of '形だけ' as 'W大 学がじゃ::: 簡単なテストをして $(+)$ 面接をして $(+)$ で入りました (W university had conducted a very simple test and an interview with my friend (and she) entered (W university))'. However, the stimulated recall session with Paul indicated that Paul did not understand the meaning of the paraphrase in Turn 6, either. This example provides an important pedagogical insight that more concrete and explicit explanation should be provided if the expressions are beyond the ZPD of the Japanese language learner. Extract 4 also indicated that language assistance given after a long interval from the original interaction is less likely to be recognised as language assistance by Japanese-language learners. Thus, it is important for Japanese native speaker participants to carefully adjust the level of language assistance according to their learner interlocutors. In cases where Japanese native speaker participants identify that intervening pedagogically is more valuable than maintaining the flow of their interactions, they should provide language assistance within a shorter interval from the original interaction. Such language assistance allows Japanese language learners to easily relate the given language assistance to the original interaction and learn effectively from the assistance. 


\section{Conclusions}

Employing Vygotsky's concept of the ZPD and assistance from experts to novices in LEPs, ${ }^{52}$ this study examined how interactions in LEP sessions between Japanese native speakers and Japanese language learners can create learning opportunities for Australian learners of Japanese. Aljaafreh and Lantolf ${ }^{53}$ assert that assistance to learners should be graduated, contingent and dialogic. Consistent with Aljaafreh and Lantolf's conditions, this study also established that Japanese native speaker participants can tactically provide language assistance within the ZPD of Japanese language learners by accurately assessing the level of their interlocutors' ZPD. They can do so by starting from minimum assistance and negotiating the level of assistance with their learner partners, and by withdrawing assistance as soon as Japanese language learners show signs of selfregulation. As to factors that Japanese native speakers use to accurately evaluate the level of Japanese language learners' ZPD, this study identified that the unique learning contexts in LEPs contribute to the accuracy. In one-on-one learning environments, Japanese native speakers can carefully observe and analyse their interlocutors' fluency levels. In addition, the informality of LEPs enables the participants to flexibly negotiate their topic of conversation and share their course assignments and learning materials. Consequently, such unique learning contexts as LEPs allow Japanese native speakers to accurately assess the ZPD of Japanese learners, and provide the appropriate level of language assistance. In addition, this study also revealed an important skill that LEP participants should develop to provide or receive language assistance to activate the ZPD of the Japanese-language learner: negotiation. As seen in Turn 3 of Extract 2, Japanese native speakers may wrongly assume that Japanese language learners understand an ongoing interaction. Therefore, it is important for Japanese language learners to honestly and overtly indicate their need for language assistance to their native speaker interlocutors, and actively negotiate the level of assistance they wish to obtain from their Japanese native speaker partners.

The findings of this study suggest significant pedagogical implications for improving learning processes and learning outcomes in LEPs. Although this study demonstrates that LEPs serve as opportunities for Japanese language learners to practice Japanese and receive language assistance in their ZPD from Japanese native speakers, not all interactions benefit Japanese language learners, as seen in Extract 4. In particular, some LEP participants have no prior experience of participating in LEPs; consequently, they may struggle to find topics, have difficulties sustaining their ongoing interactions, or be 
unsatisfied with their learning experiences in $\mathrm{LEPs}^{54}$. Given the fact that LEPs are new learning experiences for some participants, universities should pedagogically intervene to enhance the quality of interactions and learning processes in LEPs.

With regard to pedagogical intervention, Voller and Pickard ${ }^{55}$ provide useful insights for improving interactions in LEPs. Voller and Pickard identified lack of learning organisation as a cause of unsuccessful learning experiences in LEPs, quoting their participants' complaints that their interlocutor did not teach, but just chatted with them. Such dissatisfaction may emerge from the learners' strong belief that error correction is evidence of teaching, or from their high expectation of corrective feedback from their partners in LEP sessions. However, given the social aspects of LEPs, it can be difficult for Japanese native speakers to provide a large degree of error correction ${ }^{56}$. As for solutions, universities can explain to new participants in LEP orientation sessions the dual functions of LEPs, and encourage them to practice selective correction for serious errors. Moreover, problems with the learning organisation can be attributed to the participants' limited learning experiences in LEPs. As seen in Extract 4, the explanation skills of Japanese native speakers significantly impact on the comprehension of their learner interlocutors. Therefore, universities should provide prior and ongoing training so that new participants can continuously develop their interaction skills. They should encourage them to analyse how experienced participants interact tactically, share problems they encounter in LEPs, and discuss what they wish their partners to gain from the LEP sessions. Finally, Voller and Pickard ${ }^{57}$ assert that participants should provide feedback to their partners about the extent to which their language has improved. In their research, participants were not satisfied with their mastery of the target language. Given that LEPs are an informal learning context with no formal lesson structure and examination, participants may not be able to easily confirm their learning progress in LEPs. Therefore, universities can set up systems so that LEP participants can reflect on their learning experiences in LEPs, share them with other participants, and provide feedback about language development to their partners on a regular basis.

This study was a two-month case study conducted at an Australian university. The author conducted the study as a partial requirement for a four-month research subject in a Masters course. The limitations of the study are the small size of the research sample and the short research period; therefore, it is ill-advised to generalise the findings of this study to other learning contexts. However, this study clearly highlights that LEPs have the potential to increase learning opportunities for Japanese language learners studying

\footnotetext{
54 Voller and Pickard, op. cit.; Matsumoto, 'Kaiwa pātonā handobukku no sakusei to kaitei'.

55 Voller and Pickard, op. cit.

56 Nagami, op. cit.; Nishioka, op. cit.

57 Voller and Pickard, op. cit.
} 
in foreign language environments to practice and learn Japanese from Japanese native speakers. Given the fact that the participants had not experienced LEP sessions prior to this study (except for Sutono), and that the participants conducted LEPs with the same partner for only two months, their interactions in LEPs and perceptions of their learning experiences are likely to change in the long term. Therefore, it would be worthwhile to conduct longitudinal studies that trace how participants' language fluency, interactions in LEPs and perceptions of their learning experiences change over time.

\section{Acknowledgement}

I would like to express my gratitude to the four participants who devoted their time to this study and provided significant insight into LEPs. I am also grateful for the helpful suggestions and comments from my supervisor, Ms. Yano; Dr. Matthew Piscioneri of the Faculty of Arts, Monash University; and the peer reviewers for this publication. 


\section{Reference List}

Aljaafreh, A. and Lantolf, J. P., 'Negative Feedback as Regulation and Second Language Learning in the Zone of Proximal Development', The Modern Language Journal, vol. 7, no. 4 (1994), pp. 465-483.

de Guerrero, M. C. M. and Villamil, O. S., 'Activating the ZPD: Mutual Scaffolding in L2 Peer Revision', The Modern Language Journal, vol. 81, no. 1 (2000), pp. 51-68.

Gass, S. and Mackey, A., Stimulated Recall Methodology in Second Language Research (Malden: Blackwell, 2000).

Horiuchi, M., 'Gakubu ryūgakusei shien jisshi hōkoku, nihongo pātonā katsudō: Ryūgakusei to ukeire gakusei to no ryōkōna yūjin kankei keisei wo mezashite’ [学部留学生支援実施報告、日本語パートナー活動：留学 生と受け入れ学生との良好な友人関係形成を目指して], Kanda University of International Studies. Retrieved 11 October 2012, from http://www.kuis.ac.jp/icci/publications/pj_results/ssp/04_horiuchi.pdf \#search='\%E5\%AD\%A6\%E9\%83\%A8\%E7\%95\%99\%E5\%AD\%A6\%E7\%94\%9F\%E6\%94\%AF\%E6\%8F\%B4\% E5\%AE\%9F\%E6\%96\%BD\%E5\%A0\%B1\%E5\%91\%8A\%E3\%83\%BB\%E6\%97\%A5\%E6\%9C\%AC\%E8\%AA\% 9E\%E3\%83\%91\%E3\%83\%BC\%E3\%83\%88\%E3\%83\%8A\%E3\%83\%BC\%E6\%B4\%BB\%E5\%8B\%95.

Kawamura, Y., 'Intānetto jō de riyō kanōna bunshō no nan’ido sokutei shisutemu no kaihatsu [インターネット上で利 用可能な文章の難易度測定システムの開発], Yōroppa Nihongo Kyōiku [ヨーロッパ日本語教育], vol. 16 (2012), pp. 194-198.

Kawamura, Y., 'Goi chekkā wo mochiita dokkai tekisuto no bunseki’ [語彙チェッカーを用いた読解テキストの分 析], Kōza Nihongo Kyōiku [講座日本語教育], vol. 34 (1999), pp. 1-22.

Little, D. and Brammerts, H., 'Tandem Language Learning via the Internet and the International E-Mail Tandem Network', occasional paper (Dublin: Trinity College, Centre for Language and Communication Studies, 1996).

Mackey, A. et al., 'How Do Learners Perceive Interactional Feedback?', Studies in Second Language Acquisition, vol. 22, no. 4 (2000), pp. 471-497.

Markee, N., Conversation Analysis (Mahwah: Lawrence Erlbaum Associates, 2000).

Masuda, Y., 'Negotiation of Language Selection in Language Exchange Partnerships', in Marriott, H. et al. (eds.), Learning Discourse and the Discourses of Learning (Clayton: Monash University ePress, 2007), pp. 16.11-16.18.

Matsumoto, K., 'Kaiwa pātonā handobukku no sakusei to kaitei: Ryūgakusei to nihonjin gakusei no kōryū-ibunka rikai sokushin no ikkan to shite' [会話パートナーハンドブックの作成と改訂：留学生と日本人学生の 交流〜異文化理解促進の一環として〜], Journal of International Student Centre Nagasaki University [長崎 大学留学生センター紀要], vol. 12 (2004), pp. 27-39.

Matsumoto, K., 'Kaiwa puroguramu: Ryūgakusei to nihonjin gakusei no sōgo rikai ni mukete’ [会話プログラム : 留 学生と日本人学生の相互理解に向けて], Hiroshima Daigaku Ryūgakusei Sentā Kiyō [広島大学留学生セ ンター紀要], vol. 11 (2001), pp. 79-93.

Mimaki, Y. et al., 'Nihongo gakushūsha to nihongo kyōryokusha ni yoru sōgo katsudō: Nihongo pātonā dōnyū' [日本 語学習者と日本語協力者による相互活動：日本語パートナー導入], Ōsaka Daigaku Ryūgakusei Sentā Kenkyū Tabunka Shakai to Ryūgakusei Koryū [大阪大学留学生センター研究多文化社会と留学生交流], vol. 3 (1999), pp. 101-119.

Monash University, 'Find Out More about the Language Exchange Program: What Students Say about the Program'. Retrieved 12 October 2012, from http://www.monash.edu.au/health-wellbeing/get-involved/more-aboutlanguage-exchange.html. 


\section{New Voices Volume 6}

Morris, F. A. and Tarone, E., 'Impact of Classroom Dynamics on the Effectiveness of Recasts in Second Language Acquisition', Language Learning, vol. 53, no. 2 (2005), pp. 325-368.

Muraoka, T. and Mimaki, Y., 'Ōsaka daigaku toyonaka kyanpasu ni okeru nihongo pātonā no tokusei to katsudō: 1999 nendai ichigakki no jissen hōkoku oyobi kōsatsu’ [大阪大学豊中キャンパスにおける日本語パートナー の徳性と活動：1999年第一学期の実践報告および考察], Ōsaka Daigaku Ryūgakusei Sentā Kenkyū Tabunka Shakai to Ryūgakusei Koryū [大阪大学留学生センター研究多文化社会と留学生交流], vol. 4 (2000), pp. 55-65.

Nagami, M., 'Tomodachi to no kaiwa to daini gengo gakushū wa ryōritsu suru ka: L1 shiyōsha to L2 shiyōsha no kaiwa ni okeru teisei to hatsuwa enjo’ [友達との会話と第二言語学者は両立するか：L1使用者とL2使用者の会 話における訂正と発話援助], Handai Nihongo Kenkyū [阪大日本語研究], vol. 17 (2005), pp. 27-58.

Nassaji, H. and Swain, M., 'A Vygotskian Perspective on Corrective Feedback in L2: The Effect of Random Versus Negotiated Help on the Learning of English Articles', Language Awareness, vol. 9, no. 1 (2000), pp. 34-51.

Nishioka, H., 'Language Assistance in Japanese-English Language Exchange Partnerships (LEPs)', Monash University Linguistics Papers, vol. 6, no. 2 (2009), pp. 65-81.

Nunan, D., Research Methods in Language Learning (Cambridge: Cambridge University Press, 2007).

Olsson, M., 'Intelligibility: A Study of Errors and their Importance' (Department of English, Gothenburg University: Gothenburg, 1972).

Stoller, F. L. and Hodges, R., 'Examining the Values of Conversation Partner Programs', Applied Language Learning, vol. 6, nos. 1 \& 2 (1995), pp. 1-12.

Takeuchi, O., Yori yoi gaikokugo gakushūhō wo motomete: Gaikokugo gakushū seikōsha no kenkyū [よりよい外国語学 習法を求めて：外国語学習成功者の研究] (Tokyo: Shōhakusha, 2003).

The University of Adelaide, 'Language and Cultural Exchange Program'. Retrieved 12 October 2012, from http://www. international.adelaide.edu.au/support/lcep/.

The University of New South Wales, 'Language and Conversation Skills'. Retrieved 12 October 2012, from http://www. internationalstudent.unsw.edu.au/development/language.html.

Voller, P. and Pickard, V., 'Conversation Exchange: A Way Towards Autonomous Language Learning', in Pemberton, R. (ed.), Taking Control: Autonomy in Language Learning (Hong Kong: Hong Kong University Press, 1996), pp. 115-131.

Vygotsky, L. S., Mind in Society (London: Harvard University Press, 1978).

Wertsch, J. V., Vygotsky and the Social Formation of Mind (Cambridge: Harvard University Press, 1985).

Wertsch, J. V., 'The Zone of Proximal Development: Some Conceptual Issues', in Rogoff, B. and Wertsch, J. V. (eds.), Children's Learning in the Zone of Proximal Development (San Francisco: Jossey-Bass, 1984), pp. 7-18.

Wertsch, J. V., 'From Social Interaction to Higher Psychological Processes: A Clarification and Application of Vygotsky's Theory', Human Development, vol. 22, no. 1 (1979), pp. 1-22.

Wertsch, J. V. and Hickmann, M., 'Problem Solving in Social Interaction: A Microgenetic Analysis', in Hickmann, M. (ed.), Social and Functional Approaches to Language and Thought (Orlando: Academic Press, 1987), pp. 251-266. 
Wilson, A. H., 'Conversation Partners: Helping Students Gain a Global Perspective through Cross-cultural Experiences', Theory in Practice, vol. 32, no. 1 (1993), pp. 21-26.

Woodin, J. 'Tandem Learning as an Intercultural Activity', in Byram, M. et al. (eds.), Developing Intercultural Competence in Practice (Clevedon, England: Multilingual Matters, 2001) pp. 189-202.

Yorozu, M., 'Interaction with Native Speakers of Japanese: What Learners Say', Japanese Studies, vol. 21, no. 2 (2001), pp. 199-213. 